\title{
Analisis Hasil Improvisasi SEO dengan Metode Hybrid Modified MCDM untuk Peningkatan Peringkat Dan Trafik Kunjungan Website UMKM
}

\author{
Silvester Dian Handy Permana ${ }^{[1]}$, Ketut Bayu Yogha Bintoro ${ }^{[2]}$ \\ Program Studi Teknik Informatika, Fakultas Industri Kreatif dan Telematika, Universitas Trilogi, Jakarta ${ }^{[1],[2]}$ \\ e-mail : handy@trilogi.ac.id ${ }^{[1]}$, ketutbayu @trilogi.ac.id ${ }^{[2]}$
}

\begin{abstract}
SEO (Search engine Optimization) saat ini merupakan hal yang wajib ada di dalam website yang dibuat. SEO dapat membantu website agar dapat dicari di mesin pencarian seperti Google, Bing, dan Yahoo. Namun, penerapan SEO yang standar tidak dapat membuat website menduduki peringkat atas dalam pencariannya. Hal ini dikarenakan banyak website sudah menerapkan teknik SEO yang standar sebagai bantuan untuk pencariannya. Metode Hybrid Modified MCDM dapat mempengaruhi mesin pencari untuk menentukan website mana yang paling cocok dengan pencarian yang ada. Penelitian ini memproyeksikan penerapan SEO yang telah dimodifikasi kepada website UMKM agar dapat menjadi peringkat paling atas. Dengan menjadi peringkat paling atas dalam mesin penelusuran diharapkan dapat membantu calon pelanggan dalam mencari website UMKM sehingga dapat meningkatkan perekonomian dari UMKM
\end{abstract}

Keywords - SEO (Search engine Optimization); Metode Hybrid Modified MCDM; Mesin Penelusur; Website.

\section{Pendahuluan}

Pada era teknologi seperti zaman saat ini, banyak Usaha Mikro Kecil dan Menengah (UMKM) sudah memanfaatkan teknologi untuk mengembangkan bisnisnya. Pemanfaatan teknologi tersebut dapat berupa website dengan company profile dan toko onlinenya, penggunaan akun sosial media untuk berjualan dan sarana promosi, serta penggunaan media chatting sebagai alat bantu komunikasi dengan pelanggannya. Di dalam pemanfaatan website sebagai media promosi dan akualisasi usahanya tersebut sudah banyak yang menggunakan Search engine Optimization (SEO) untuk mencapai peringkat paling atas dalam mesin pencari website atau Search engine. Beberapa dari mereka sudah mempunyai strategi untuk memenangkan peringkat atas dalam Search engine sehingga penggunaan SEO yang standar tidak dapat mengangkat suatu website menjadi peringkat atas dalam Search engine [1].

Berbagai penelitian yang menghasilkan strategi dalam SEO ini sudah dikembangkan oleh pengusaha UMKM. Tidak sedikit juga dari mereka menggunakan jasa SEO untuk mendongkrak website usahanya. Di dalam situasi persaingan pemanfaatan teknologi seperti ini, para pelaku UMKM yang sedang berkembang sulit untuk mendapatkan mangsa pasar dari penelusuran di Search engine. Para pengusaha UMKM membutuhkan solusi yang terbaik untuk optimalisasi di dalam Search engine menggunakan teknik dan penelitian yang terbaru [2].

Penelitian terbaru mengenai SEO dilakukan oleh [3] yang mengembangkan SEO dengan mengkombinasikan SEO dengan Multiple Criteria Decision Making (MCDM) yang sudah dimodifikasi. Penelitian ini memodifikasi 6 kriteria SEO yang berada di website dan dianggap dapat meningkatkan peringkat pencarian pada Search engine. Namun, penelitian ini baru hingga pengembangan modifikasi SEO dan belum hingga penerapannya terutama dalam bisnis UMKM.

Penelitian ini akan menganalisis hasil dari penelitian sebelumnya. Analisis yang digunakan dalam penelitian ini menggunakan website UMKM yang baru dan yang sudah ada sebelumnya untuk dibandingkan dalam pemeringkatan di Search engine. Penelitian ini akan menerapkan dan menguji ke 6 kriteria yang telah dimodifikasi sebelumnya untuk didapatkan data dari hasil pencarian dalam Search engine.

Penelitian ini diharapkan dapat meningkatkan peringkat pencarian bisnis UMKM yang baru dibentuk dan yang sudah berkembang sebelumnya di dalam Search engine. Peningkatkan peringkat pencarian dalam Search engine nantinya akan membantu bisnis UMKM mendapatkan pelanggan baru. Hasil akhir dari penelitian ini untuk bantu keberlangsungan UMKM yang ada di Indonesia.

\section{TINJAUAN PUSTAKA}

Penelitian utama yang menjadi dasar pada penelitian ini dilakukan oleh [3]. Penelitian ini ini menetapkan model keputusan peringkat mesin pencari untuk administrator untuk meningkatkan kinerja situs web yang memenuhi kebutuhan pengguna. Untuk menyelidiki keterkaitan dan bobot yang berpengaruh di antara kriteria SEO dan mengevaluasi kesenjangan kinerja untuk mencapai tingkat aspirasi di dunia nyata, penelitian ini menggunakan kombinasi beberapa model pembuatan keputusan, termasuk percobaan pembuatan 
keputusan dan laboratorium evaluasi (DEMATEL), Proses jaringan analitik berbasis DEMATEL (disebut DANP), dan VlseKriterijumska Optimizacija I Kompromisno Resenje (VIKOR). Temuan empiris menemukan bahwa kriteria SEO mengakui hubungan self-effect berdasarkan teknik DEMATEL. Menurut Influential Network Relation Map (INRM), pengoptimalan situs web eksternal adalah dimensi prioritas utama yang perlu ditingkatkan ketika menerapkan SEO. Penelitian ini menggunakan enam kriteria untuk evaluasi, meta tag adalah kriteria paling signifikan yang mempengaruhi peringkat mesin pencari, diikuti oleh kata kunci dan desain situs web. Evaluasi peringkat dalam mesin pencari mengungkapkan bahwa situs web baru terendah akan menjadi contoh optimal bagi administrator situs web untuk membuat situs web peringkat atas selama penelitian ini. Penelitian yang akan dilaksanakan merupakan kelanjutan dari penelitian ini.

Penelitian yang dilakukan oleh [4] menganalisis strategi optimasi Search engine menggunakan data mining. Hasil penelitian ini menampilkan beberapa gambar simulasi dalam semua strategi optimisasi mesin pencari. Strategi optimasi mesin pencari dapat mencapai identifikasi yang sangat akurat dari kategori informasi, mendapatkan hasil yang ideal dalam mesin pencari optimasi hasilnya. Optimasi mesin pencari dapat juga dengan mengurangi waktu pengaksesan website karena mesin mencari secara real-time. Jaringan saraf tiruan juga dapat memberikan hasil yang lebih akurat kepada pengguna meningkatkan strategi optimasi mesin pencari. Penelitian yang akan dilaksanakan tidak menggunakan jaringan syaraf tiruan dan hanya mengimplementasikan penelitian yang sudah ada sebelumnya untuk usaha UMKM.

Penelitian yang dilakukan oleh [5] menganalisis salah satu search engine yang terkenal yaitu Google. Search engine ini mempunyai metode untuk pengindeksan gambar. Metode ini membandingkan expired domain atau domain yang telah digunakan sebelumnya dengan berbagai gambar yang diupload ke dalam search engine. Hal ini dilakukan karena banyak orang beranggapan bahwa menggunakan expired domain, website lebih cepat terindeks dan lebih unggul peringkatnya pada search engine daripada menggunakan domain yang baru. Penelitian ini menganalisa Google image indeks dengan melakukan perbandingan penggunaan expired domain dan domain baru dalam studi kasus toko online. Hasil dari penelitian yang dilakukan ini mempelajari mengenai pengaruh Expired Domain dengan pengindeksan gambar di satu search engine yaitu Google.

Penelitian mengenai analisis kompetitif dari website retail menggunakan search engine marketing dilakukan oleh [6]. Penelitian ini menyimpulkan bahwa SEO dapat digunakan untuk meningkatkan visibilitas situs web dan meningkatkan pendapatan penjualan. Penelitian ini berfokus pada hubungan antara strategi Search engine Marketing (SEM) dan teknik SEO untuk pencarian organik dan berbayar. Penelitian ini juga membahas dampak peringkat situs web yang positif dan negatif dan bagaimana peringkat tersebut dapat terjadi serta dapat ditingkatkan dengan mengadopsi praktik yang SEOfriendly. Penelitian ini memasarkan situs web startup di industri ritel yang kompetitif dan menganggap bahwa peningkatan peringkat dalam search engine adalah tugas yang menantang. Penelitian ini memberikan ide kepada pemilik situs web tentang bagaimana situs web harus dibuat, diluncurkan, dan dipelihara dengan memastikan traffic dan pendapatan. Namun penelitian ini hanya dapat diimplementasikan secara praktis di situs web perusahaan startup ritel.

Penelitian mengenai manipulasi SEO dalam hasil search engine dalam pemilu Amerika Serikat pada tahun 2016 dilaksanakan oleh [7]. Pada penelitian ini, Metaxas mengemukakan bahwa Search engine dapat dimanipulasi untuk memenangkan suatu kontes pemilu, politik, agama, dan sosial tertentu. Proses manipulasi ini melibatkan Web Spammers yang digunakan untuk menduplikat suatu informasi yang sama dari suatu web ke web lainnya sehingga keangkatlah suatu hal isu ke peringkat paling atas dalam mesin pencarian. Penelitian ini didasarkan oleh masyarakat Amerika Serikat yang berusaha mencari informasi mengenai calon pemimpinnya dengan mencari dalam search engine. Kesempatan seperti ini digunakan oleh oknum yang ingin memenangkan seorang kandidat yang sedang bertanding. Penelitian ini juga menjadikan refrensi dari Google dalam memperbaiki algoritma pencarian yang dibuatnya. Penelitian ini memiliki dampak bagi Google dalam menampilkan informasi dari website yang terpercaya sebagai prioritas utamanya. Search engine yang lain seperti Yahoo atau Bing belum memiliki algoritma untuk menghindari web spammers ini.

\section{Metodologi Penelitian}

Metodologi penelitian yang dipakai dalam penelitian ini adalah perhitungan kuantitatif yang melibatkan perhitungan jumlah pengunjung pada situs dengan menggunakan Search Engine Result Page (SERP) yang dipunyai oleh Google. Sebelum dilakukan optimalisasi dengan SEO, peneliti memasang mesin penghitung jumlah kunjungan di dalam situs yang akan diteliti. Hal ini dicatat sebagai nilai awal dalam perhitungan optimalisasi situs dengan SEO yang akan diterapkan. Setelah menggunakan mesin penghitung traffic, maka dilakukan langkah-langkah SEO yang dapat dilihat pada gambar 1. Pada akhir penelitian, didapatkan hasil peningkatan jumlah kunjungan pada situs flaviaclothing.com yang menjadi indikator optimalisasi situs.

Metode penelitian yang digunakan pada penelitian ini digambarkan pada Gambar 1 dibawah ini. 


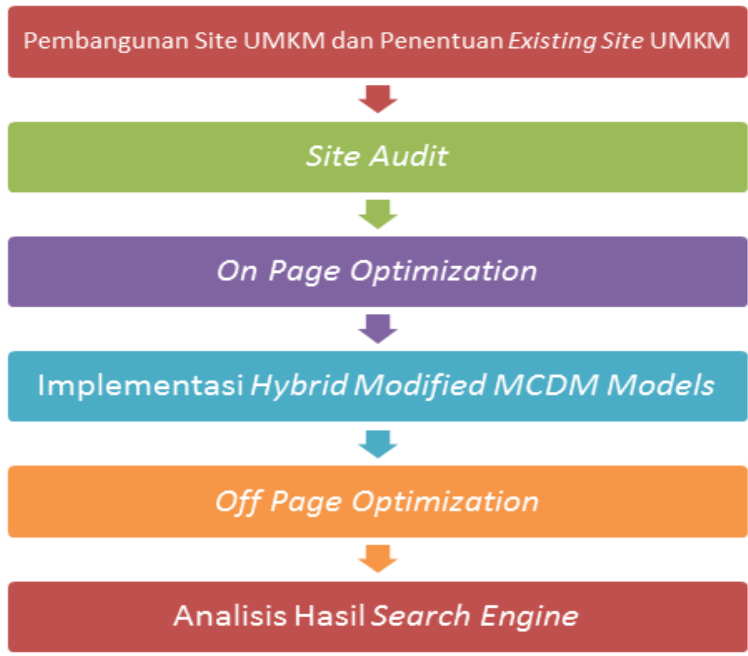

Gambar 1. Metode Penelitian

Alur Metode Penelitian yang digambarkan pada Gambar 1 memiliki beberapa langkah sebagai berikut :

1. Pembangunan Site UMKM dan Penentuan Existing Site UMKM

Di dalam proses ini akan dibangun sebuah website UMKM yang baru akan dilaksanakan untuk membuat bahan penelitian ini. website yang dibangun ini menggunakan CMS dari Wordpress dimana pembangunan ini juga memperhatikan aspek SEO disetiap halaman yang dibangunnya.

2. Site Audit

Proses ini adalah mengaudit website yang akan dipakai sebagai bahan penelitian ini. Proses audit yang ada di dalam penelitian ini ada 12 yaitu Total Readable Content, Internal Links, Average Speed, Broken Links, Canonical URL Check, (Flash, Frames and Ajax), Google banned URLs, Site Map, Site Index, Tags and Meta tags, Competitor Analysis, Search engine Page Results.

3. On Page Optimization

Pada bagian ini, kami mengusulkan pendekatan kami untuk mengoptimalkan situs web secara internal berdasarkan audit situs pada tahap 2. Kegiatan utama dalam fase ini adalah penelitian kata kunci. Daftar kata kunci yang disarankan perlu disiapkan oleh analis berdasarkan saran / umpan balik yang dicari dari klien. Setelah ini, situs web harus diisi secara internal dengan kata kunci dengan menerapkannya di tempat di manamana yaitu, dalam judul, tag, metatag, dan konten dari halaman web.

4. Implementasi Hybrid Modified MCDM Models

Bagian ini mengimplementasi Hybrid Modified MCDM Models dari penelitian sebelumnya. Hal ini sebagai bagian inti dari penelitian ini.

5. Off Page Optimization

Pengoptimalan Off Page ini berhubungan dengan praktik yang melaluinya situs web dan kontennya disebarkan melalui Internet untuk meningkatkan peringkat situs web Google dan posisi yang lebih baik di Search
Engine Results Page (SERP). Strategi pengoptimalan di luar halaman harus dikembangkan berdasarkan pada SERP dan analisis pesaing yang dilakukan selama audit. Itu Proses utama dalam fase ini adalah membangun link atau disebut dengan backlinks generation.

6. Analisis Hasil Search engine

Di dalam proses ini akan ditarik kesimpulan mengenai peringkat website tersebut berdasarkan hasil pencarian search engine yaitu Google, Yahoo, dan Bing.

Dari langkah-langkah tersebut, maka diharapkan jumlah kunjungan pada situs http://flaviaclothing.com dapat meningkat seiring dengan peningkatan hasil pencarian dalam search engine. Pada akhir penelitian diharapkan situs UMKM ini mendapatkan hasil pencarian di halaman pertama dalam pencarian di search engine Google, Yahoo, dan Bing.

\section{PEMBAHASAN}

Website yang dibangun pada penelitian ini adalah website mengenai penjualan pakaian wanita dalam situs http://flaviaclothing.com. Situs ini menjual pakaian wanita mulai dari atasan, jeans, dan pakaian luar seperti sweater atau cardigan. Situs ini merupakan pengembangan dari toko online Flavia Clothing yang berasal dari media sosial Instagram @ flavia.clothing. Website ini dibuat menggunakan CMS dari Wordpress selama 2 minggu dengan konten yang belum dimasukkan elemen SEOnya.

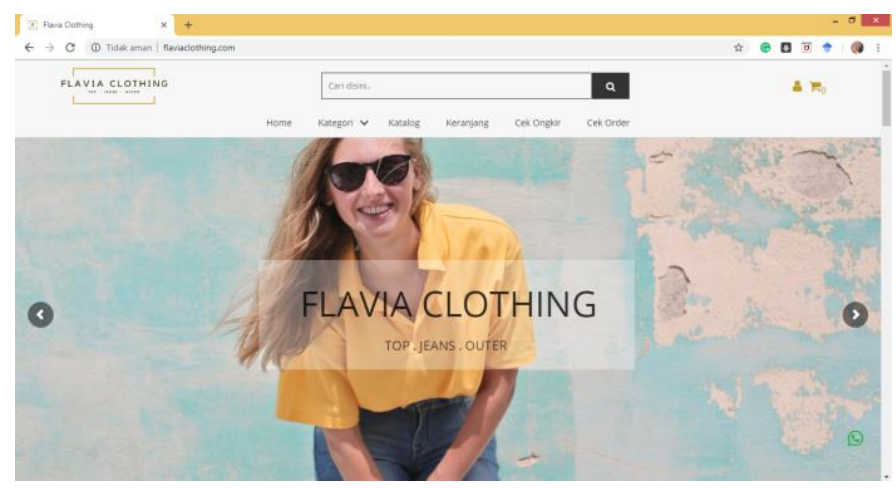

Gambar 2. Tampilan situs http://flaviaclothing.com/

Gambar 2 diatas menunjukkan bahwa situs http://flaviaclothing.com telah berhasil dibuat dan mempunyai fungsi sebagai toko online. Pengujian mengenai sistem toko online dalam website ini telah dilakukan dan mendapatkan hasil yang prima dan siap untuk dipakai oleh umum.

Tahapan selanjutnya adalah mengaudit site yang akan dioptimalisasi SEOnya. Dalam audit ini ada 12 hal yang perlu diperhatikan. Tahap ini memeriksa konten yang dapat dibaca di dalam situs Flavia Clothing. Situs tersebut memiliki berbagai elemen yang dapat dibaca oleh Google yakni dari front page, gambar slide, kategori, gambar barang, deskripsi 
barang, tentang kami, kontak kami, privacy policy, customer support, pembayaran, panduan ukuran, dan pengembalian. Situs ini memiliki 12 readable content yang dapat dibaca oleh mesin penelusur dan siap untuk dilakukan indexing. Internal Links yang ada di dalam website ini sudah diarahkan untuk mendukung SEO yang akan diimplementasikan. Average Speed merupakan berapa lama waktu respons dari website untuk dapat tampil sempurna. Didapatkan waktu rata-rata dari beberapa kali percobaan menuju website adalah 3.06 detik. Broken Links pada website ini tidak ada, semua link pada page akan menghasilkan respons dari website. Canonical URL Check ada pada website ini. website ini menerapkan SEO Ultimate merupakan tools plugin yang ada dalam website yang berguna untuk memudahkan mesin penelusur dalam mencari setiap kata yang ada dalam page yang terpisah. Google banned URLs sudah ada di dalam meta data di situs ini, Site Map dalam situs ini belum ada, Site Index sudah ada di dalam website ini, Tags and Meta tags sudah ada di dalam page maupun konten yang ada di website ini, Competitor Analysis yang ada sangat tinggi dan sudah aware terhadap search engine. Sedangkan untuk Search engine Page Results pada awal pembuatan website ini, flaviaclothing.com menduduki peringkat page diatas 10 untuk pencarian dari google, yahoo, dan bing.

On-page optimization dalam adalah suatu unsur yang sangat penting untuk mendapatkan peringkat yang paling atas dalam mesin penelusur. Flavia Clothing telah menerapkan on page optimization dalam websitenya. Dimulai dari segi konten website ini memiliki konten yang unik dimana konten yang diciptakan tidak berasal dari website lainnya sehingga memudahkan mesin browser untuk mencari website Flavia Clothing ini. Sedangkan untuk keyword atau kata kunci Flavia Clothing menggunakan kata kunci yang umum seperti pakaian murah, pakaian murah jakarta, pakaian wanita, dan sebagainya di setiap meta data dari konten tersebut. Hal ini membantu website Flavia Clothing untuk mendapatkan peringkat atas dalam pencarian di search engine. Dalam segi judul nama barang, peneliti memberikan dalam judul tersebut dengan menambahkan kata "baju kekinian cewek murah wanita grosir bahan halus kualitas import" hal ini juga dilakukan dalam penjualan di marketplace shopee, Flavia Clothing mendapatkan jumlah pencarian yang banyak. Hal ini juga tentunya dapat menambah node dalam pencarian di search engine. Dalam segi new url yang ada dalam Flavia Clothing juga sudah ditambahkan unsur SEOnya sehingga dapat membantu menaikkan pencarian di search engine tersebut. Dalam Meta description di dalam gambar di website Flavia Clothing ini telah ditambahkan metadata yang sesuai dengan unsur SEO nya. Meta data yang sesuai dengan unsur SEO di sini dimasukkan dalam judul, subjek, tags, comment, author, dan copyright yang ada di setiap gambar. Meta data yang disematkan pada gambar dapat dilihat pada gambar 3 .

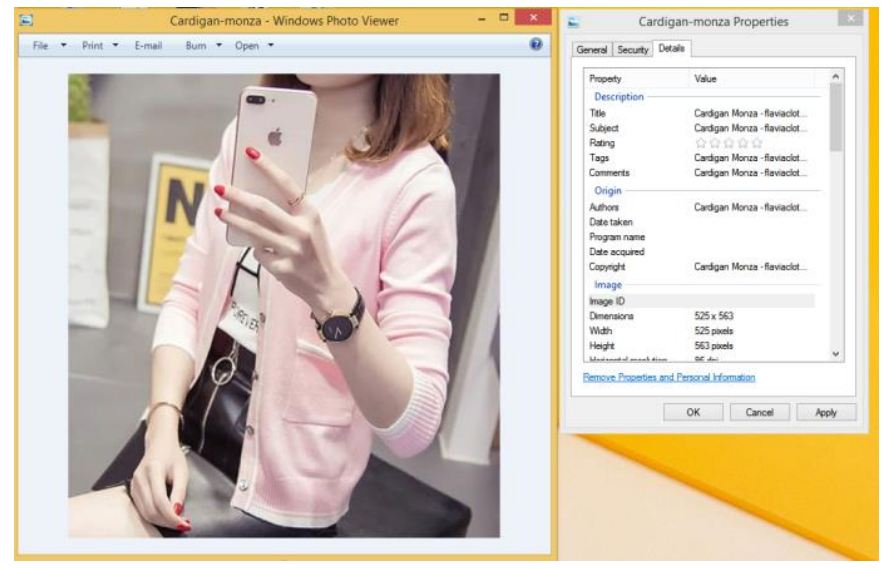

Gambar 3. Meta data pada gambar di situs http://flaviaclothing.com/

Website Flavia Clothing ini juga memiliki social sharing di mana pengguna website ini dapat menyebarkan informasi mengenai produk melalui sosial media Facebook, Twitter, dan Google Plus. Penggunaan social sharing pada salah satu produk dalam Flavia Clothing dapat dilihat pada gambar 4 di bawah ini.

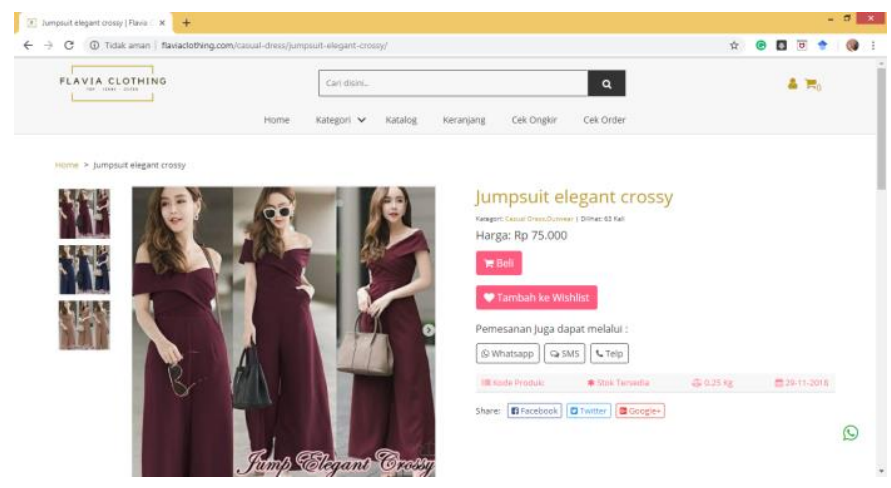

Gambar 4. Social Sharing pada situs http://flaviaclothing.com/

Dalam Implementasi Hybrid Modified MCDM Models di dalam SEO untuk situs http://flaviaclothing.com, peneliti akan mengambil kriteria dalam penilaian dari penelitian [3]. Kriteria tersebut antara lain desain website, Meta tags, dan pemilihan keyword untuk internal website optimization. Sedangkan untuk external website optimization mempunyai kriteria site guide, sosial media, dan linkage.

Bagian ini, peneliti akan menguji kembali kriteria yang dipakai dalam penelitian tersebut terhadap 10 orang yaitu 5 orang yang berpengalaman membangun SEO dari sebuah website, 2 orang web developer, dan 3 orang pengguna internet yang biasa melakukan transaksi pembelian secara online.

Dari hasil kuisioner yang mengarahkan kepada kriteria penilaian dalam penelitian [3], didapatkan bahwa nilai untuk 
desain dari flaviaclothing.com memiliki nilai 7.5 skala 10 dimana penilaian ini cukup bagus mengenai desain dari website ini untuk menarik minat beli dari pengunjung. Desain website ini dapat dioptimalkan antara lain dengan cara mengurangi space kosong dan memadatkan konten yang tersedia. Dalam pertanyaan mengenai meta tags dalam website yang mengandung SEO, meta tags sangat diperlukan untuk mencari kata yang sesuai dalam mesin pencarian. Meta tags sangat diperlukan dalam unsur pencarian yang ada di dalam website. Meta tags seharusnya ada disetiap page dan konten yang tersedia di dalam website untuk mendongkrak pencarian dalam search engine tersebut. Dari hasil kuisioner, ditemukan bahwa semua orang setuju bahwa meta tags dapat menaikkan pencarian yang ada di mesin penelusur. Kata kunci atau keywords merupakan kriteria ketiga yang diungkapkan dalam penelitian tersebut. Keywords untuk setiap UMKM berbeda satu dengan lainnya berdasarkan kemiripan kata (sinonim) dari barang yang dijual dalam toko online. Flavia Clothing merupakan UMKM yang berjualan pakaian. Hal ini menjadi pertanyaan kepada koresponden, keywords apa yang cocok untuk diterapkan dalam Flavia Clothing atau jika ingin membeli pakaian secara online di mesin pencari, kata kunci apa yang dicari dalam mesin pencari. Hasil jawaban dari koresponden tersebut dapat dilihat dalam tabel 1.

Tabel 1. Hasil jawaban dari keywords yang dibutuhkan dalam SEO

\begin{tabular}{|l|l|}
\hline Koresponden & Hasil \\
\hline K1 & $\begin{array}{l}\text { Pakaian, Pakaian Murah, Pakaian Murah Jakarta, Baju, } \\
\text { Baju Wanita, }\end{array}$ \\
\hline K2 & Baju, Baju Murah, Baju grosir, cardigan, outer, \\
\hline K3 & Busana, busana murah, \\
\hline K4 & $\begin{array}{l}\text { Grosir baju, baju tanah abang, sweater, cardigan, olshop } \\
\text { murah, pusat baju murah, }\end{array}$ \\
\hline K5 & $\begin{array}{l}\text { Grosir baju bandung, baju murah bandung, grosir baju } \\
\text { online, pusat pakaian online, baju online murah, grosir } \\
\text { baju murah, baju tanah abang }\end{array}$ \\
\hline K6 & $\begin{array}{l}\text { Baju olshop, baju hijab bandung, pusat baju muslim, pusat } \\
\text { baju grosir, pusat baju hijab, busana muslim, grosir hijab, } \\
\text { grosir baju bandung, baju murah bandung, grosir baju } \\
\text { online, pusat pakaian online, baju online murah, } \\
\text { grosirbajumurah, bajutanahabang }\end{array}$ \\
\hline K7 & $\begin{array}{l}\text { Grosir baju, baju murah, dress pesta, baju terupdate, dress } \\
\text { kekinian, baju bandung, dress couple }\end{array}$ \\
\hline K8 & $\begin{array}{l}\text { Baju murah, dress, gamis syari, baju baru, baju terbaru, } \\
\text { gamis baru }\end{array}$ \\
\hline K9 & $\begin{array}{l}\text { Grosir jacket, grosir jaket bandung, grosirrajut, sweater } \\
\text { murah, grosir baju murah, cardigan murah, baju couple, } \\
\text { olshop murah, trusted olshop, pusat baju murah, olshop, } \\
\text { grosir pakaian, baju murah bandung, bajumurah, grosir } \\
\text { hijab, belanja baju, bandung, grosir baju, grosir sweater, } \\
\text { grosir hijab bandung }\end{array}$ \\
\hline K10 & $\begin{array}{l}\text { Gamis syari import, baju hijab, baju import, baju gamis, } \\
\text { grosir baju, baju murah, baju hijab murah, olshop murah, } \\
\text { baju import, online shop murah, online shop baju murah, } \\
\text { pusat baju murah, gamis murah, baju hijab keren, baju } \\
\text { hijab kekinian, gamis import, gamis import murah, gamis } \\
\text { import branded, baju import murah, grosir gamis murah, } \\
\text { baju gamis murah }\end{array}$ \\
\hline
\end{tabular}

Dari hasil jawaban tersebut dapat dilihat bahwa kata baju muncul sebanyak 49 kali (24\%), kata murah muncul sebanyak 30 kali (14\%), kata grosir muncul sebanyak 20kali (10\%), kata bandung muncul sebanyak 10kali (5\%), kata gamis muncul sebanyak 10kali $(5 \%)$, kata hijab muncul sebanyak 9 kali (4\%), dan kata pusat muncul sebanyak 8 kali (4\%). Dari kata keyword yang didapatkan maka dapat disimpulkan beberapa kata yang sesuai dengan toko online yang diangkat adalah baju, murah, grosir, gamis, dan bandung. Hal ini sesuai dengan yang digunakan pada SEO on page yang telah dilakukan.

Hal selanjutnya yang diperlukan dalam analisis Implementasi Hybrid Modified MCDM Models adalah mengenai external website optimization. External website optimization disini mempunyai kriteria site guide, sosial media, dan linkage. Site guide ini merupakan peta situs secara keseluruhan dimana situs ini memiliki link antara page 1 dengan lainnya. Penerapan site guide secara parsial ini dalam Flavia Clothing sendiri sudah ada disetiap tampilan barang yang akan dijual dalam kolom mengenai barang lain yang direkomendasikan. Dengan hal ini maka antara satu barang dengan barang yang lain terkoneksi dan mempunyai pertukaran node link yang dapat membuat sirkular dalam pagenya. Flavia Clothing perlu juga menambahkan Site Guide berupa site map. Site map sendiri mempunyai peran untuk menampilkan semua link dalam website tersebut yang tersaji dalam suatu page tertentu. Site map yang sebaiknya dibuat ini dapat membangun link baru kesemua page dalam website tersebut.

Media Sosial merupakan hal yang perlu diperhatikan juga dalam External website optimization. Hal ini tentu saja memberikan link yang berkaitan antara media sosial dan website ini. link yang terbangun sebaiknya menggunakan 2 arah yaitu baik dari media sosial ke website maupun website ke media sosial. Hal ini sudah diterapkan oleh website Flavia Clothing yang mengarah kepada media sosial Facebook, Twitter, dan Google + sedangkan media sosial Instagram belum ditambahkan. Media sosial Instagram sendiri sudah dibuat link ke fanpage Facebook secara independen sehingga yang dipost dalam Instagram sudah dipost juga kedalam media sosial Facebook. Penerapan media sosial ini juga sudah dioptimalisasi dalam social sharing pada gambar 4 .

Hal yang selanjutnya yang perlu diperhatikan dalam External website optimization adalah Linkage. Linkage merupakan keterkaitan antara website luar dengan website Flavia Clothing ini. keterkaitan yang ditimbulkan disini merupakan akses link yang menjadi jembatan untuk masuk ke website Flavia Clothing. Dalam meningkatkan ranking SEO sewajarnya menggunakan linkage ini sehingga banyak "pintu masuk" yang tercipta untuk pendatang baru ke website ini. Linkage seharusnya juga mempunyai peran dalam memastikan pengunjung situs dapat menemukan informasi-informasi yang diinginkan dengan mudah dan tepat sasaran. Linkage yang dibangun ini berdasarkan informasi mengenai apa yang dicari dari pengunjung situs.

Dari semua hal yang menjadi kriteria dalam Implementasi 
Hybrid Modified MCDM Models diharapkan dapat membantu menaikkan ranking hasil pencarian dalam mesin penelusur. Dengan adanya proses tersebut, maka dapat dipastikan adanya kenaikan jumlah pengunjung situs sehingga dapat meningkatkan juga penghasilan yang didapatkan melalui toko online ini.

Langkah selanjutnya adalah dengan mengoptimalisasi Off Page Optimization. Optimasi offpage ini mempunyai definisi sebagai teknik yang dapat membantu situs web untuk meningkatkan peringkatnya pada halaman hasil mesin pencari dengan cara diluar website itu sendiri. Off Page Optimization mempunyai faktor yang berfungsi di luar halaman web. Faktor peringkat ini tidak secara langsung dikendalikan oleh developer website dengan merubah websitenya melainkan dengan memperbanyak link yang mengarahkan ke website ini.

Off page SEO adalah proses jangka panjang dan memakan banyak waktu untuk berproses. Hal ini termasuk memperoleh backlink (tautan balik) ke halaman web dari situs lain termasuk dari media sosial. Off page mempunyai faktor yang bekerja di belakang untuk meningkatkan peringkat pencarian.

Website Flavia Clothing telah mempunyai banyak link yang mengarahkan pada website tersebut. Website Flavia Clothing sudah tersebar diberbagai blog, media sosial, dan berbagai website forum. Pertukaran link ini dapat didapatkan karena adanya kerjasama yang mencantumkan link dari Flavia Clothing kedalam website atau media sosial tersebut.

Flavia Clothing juga sudah mempunyai event "Give away" yang mampu meningkatkan Off page SEOnya dengan cara menyebarkan foto dari salah produk ke media sosial pengunjungnya. Dalam event ini juga diberikan aturan untuk mencantumkan alamat websitenya sehingga link alamat website dari Flavia Clothing dapat diakses dari setiap profile pengunjungnya. Hal ini tentu saja menambah ranking dari Flavia Clothing di mesin penelusur website.

Setelah dilakukan analisis, pengoptimalan melalui onpage dan offpage, serta pengimplementasian Hybrid Modified MCDM Models maka diperlukan analisis hasil search engine yang menyeluruh sebagai akhir dari penelitian ini. Hal ini tentu saja mengukur dampak adanya SEO yang menggunakan berbagai metode optimalisasi dengan website yang belum menggunakan SEO.

Sebelum penelitian ini dilakukan, situs http://flaviaclothing.com memakai Search Engine Results Page (SERP) untuk menghitung banyaknya jumlah kunjungan ke situs tersebut. Dari hasil SERP tersebut didapatkan bahwa adanya peningkatan jumlah kunjungan yang dapat dilihat pada tabel 2 .

Tabel 2. Hasil Search Engine Results Page (SERP)

\begin{tabular}{|c|l|}
\hline Minggu ke & Hasil \\
\hline 1. & 0 \\
\hline 2. & 12 \\
\hline 3. & 110 \\
\hline 4. & 151 \\
\hline 5. & 402 \\
\hline 6. & 504 \\
\hline
\end{tabular}

\begin{tabular}{|c|c|}
\hline Minggu ke & Hasil \\
\hline 7. & 1001 \\
\hline 8. & 1321 \\
\hline 9. & 1723 \\
\hline 10. & 1993 \\
\hline 11. & 2246 \\
\hline 12. & 2743 \\
\hline 13. & 3011 \\
\hline 14. & 3378 \\
\hline 15. & 3785 \\
\hline 16. & 4389 \\
\hline
\end{tabular}

Dari hasil SERP dalam tabel 2 diatas dapat dilihat rata-rata jumlah pertumbuhan trafik baru setiap minggunya adalah 292.6 kunjungan. Pertumbuhan ini disebabkan karena jumlah simpul dan konten yang memiliki unsur SEO yang meningkat dari minggu pertama hingga minggu ke 16. Grafik peningkatan jumlah kunjungan di situs http://flaviaclothing.com dapat dilihat pada gambar 5 .

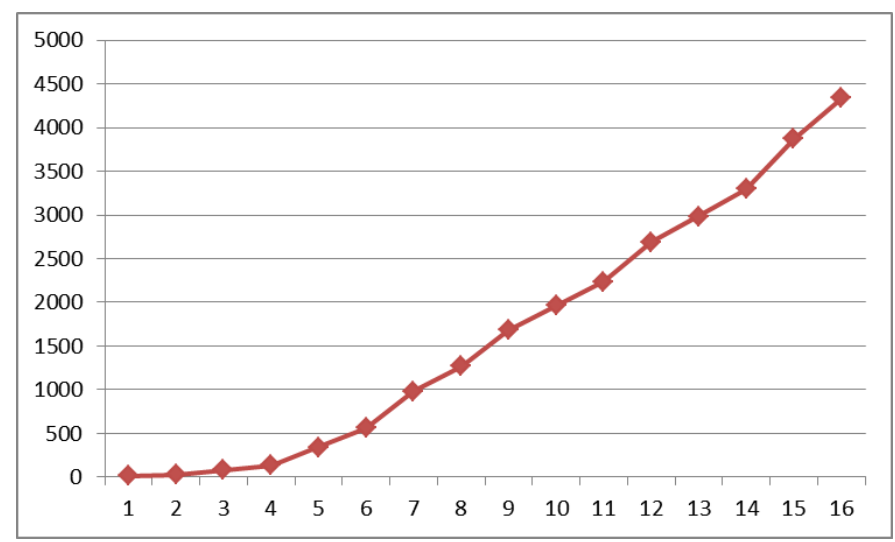

Gambar 5. Grafik pengunjung situs http://flaviaclothing.com/

Dari trafik jumlah pengunjung website dapat dilihat adanya peningkatan jumlah pengujung setiap minggunya. Jumlah total pengunjung dari awal dibuat websitenya hingga setelah dilakukan optimasi terdapat kenaikan dari 12 pengunjung diminggu kedua hingga 4.389 pengujung diminggu ke - 16 yang terdapat pada gambar 5. Hal ini menandakan bahwa adanya dampak yang signifikan dalam peningkatan jumlah pengunjungnya.

Kenaikan jumlah kunjungan berdampak juga pada kenaikan jumlah transaksi pembelian dalam situs http://flaviaclothing.com. Pembelian yang dilakukan oleh pengunjung situs ini sejalan dengan jumlah kunjungan. Transaksi yang terjadi pada situs ini, didapatkan dari kunjungan pengguna baru maupun pengunjung yang sudah pernah membeli disitus ini pada minggu sebelumnya (repeat order) grafik jumlah transaksi pada situs ini dapat dilihat pada gambar 6 dibawah ini. 


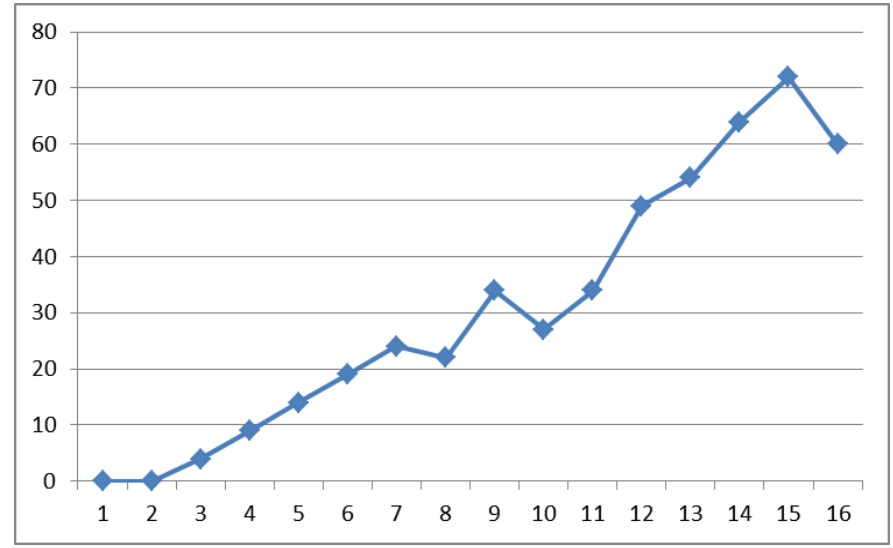

Gambar 6. Jumlah Pembelian dari situs http://flaviaclothing.com/

Dari gambar 6 diatas dapat dilihat bahwa adanya kenaikan jumlah pembelian yang signifikan berdasarkan jumlah pengunjung situs Flavia Clothing. Jika dilihat dari gambar 5 dan dibandingkan dengan gambar 6 maka dapat disimpulkan bahwa ada sekitar $2 \%$ dari pengunjung yang membeli setiap minggunya.

\section{PENUTUP}

Kesimpulan yang dapat diambil dari penelitian ini bahwa Improvisasi SEO dengan Metode Hybrid Modified MCDM dapat Peningkatan Peringkat dan Trafik Kunjungan Website UMKM. Penelitian ini membuktikan bahwa SEO sangatlah penting untuk menaikkan ranking pencarian dalam website dan menaikkan jumlah pengunjung website setiap minggunya. Adanya SEO juga dapat membantu para pengunjung situs mendapatkan informasi yang dibutuhkannya. Penelitian selanjutnya diharapkan dapat mengkombinasikan berbagai model SEO seperti whitehat dan blackhat SEO agar dapat memenangkan market penjualan melalui mesin penelusur.

\section{DAFTAR PUSTAKA}

[1] A. Riyanto, "Analisis Dan Penerapan Search engine Optimization Pada Website Menggunakan Metode White Hat Seo," J. Teknol. Inf., vol. 1, 2018.

[2] A. ID hadiana, "Model Search engine Optimization bagi Usaha Mikro Kecil dan Menengah ( UMKM ) di Bandung Barat," Jumanji, vol. 02, no. 01, pp. 31-38, 2018.

[3] H.-J. Tsuei, W.-H. Tsai, F.-T. Pan, and G.-H. Tzeng, "Improving search engine optimization (SEO) by using hybrid modified MCDM models," Artif. Intell. Rev., 2018.

[4] R. Chen, "Research on the optimization strategy of web search engine based on data mining," vol. 040027, p. 040027, 2018.

[5] S. Sujatmiko and D. Ariyus, "Analisis Google Image Index Perbandingan SEO Expired Domain dan Fresh Domain Studi Kasus Toko Online," pp. 25-30, 2018.

[6] L. Sivanandam, "Competitive Analysis of Retail Websites through Search engine Marketing Análisis competitivo de sitios web minoristas a través del marketing de búsqueda," vol. 14, no. 25, 2018.

[7] Metaxas and Pruksachatkun, "Manipulation of Search engine Results during the 2016 US Congressional Elections," Dep. Comput. Sci. Wellesley Wellesley Coll., 2017. 